\title{
The Right to Food is Clearly Stipulated in International Human Rights Law: A Number of Challenges Have Riddled Its Enjoyment in Uganda
}

\author{
Witness Nabalende \\ Lecturer \\ School of Law \\ King Ceasor University \\ Uganda
}

\begin{abstract}
The Right to Food has been accorded universal recognition as a human right and is reflected in several international and Regional instruments to which Uganda is signatory. Under the 1995 Constitution of the Republic of Uganda, the right to food is defined as a principle of state policy. More so, several legislations have been enacted to provide for the right though not explicitly. Also, policies such as the Uganda Food and Nutrition Policy (UFNP) which is based on human rights principles was adopted. In-spite of the commitment to end hunger and malnutrition through legal and policy frameworks, the percentage of the undernourished in Uganda is estimated at 19\% and the mortality rate at 141 per 1000 live births of which more than one-third is malnutrition related. These statistics clearly indicate that challenges still exist that prevent full enjoyment of the right to food in Uganda. It is therefore suggested that in order to realise the right to food there must be a law specifically providing for the right. More so it is believed that achieving food security for all demands the engagement of all stakeholders that is, government, civil society and independent monitoring institutions since they all have an important role to play in ensuring the progressive realisation of the right to food. For it is only when this is done that Ugandans will enjoy the right to food.
\end{abstract}

Key words: (Right to Food, Food Security, Hunger, Malnutrition)

\section{Introduction}

"Starvation is the characteristic of some people not having enough to eat. It is not the characteristic of there being not enough to eat. While the latter can be cause of the former, it is but of many possible causes." - Amartya Sen, Poverty and Famines, 1981

For over 50 years, there has been concern about the high prevalence of hunger and malnutrition in a world that has the capacity to feed its people. ${ }^{1}$ According to the Food and Agriculture Organization (FAO), more than one billion people are undernourished ${ }^{2}$ and over two billion suffer from a lack of essential vitamins in their food. ${ }^{3}$ Further, it is estimated that 925 million people, around the globe go to bed hungry ${ }^{4}$ and nearly six million children die every year from malnutrition or related diseases. ${ }^{5}$ This has become a "silent holocaust, repeated year after year." ${ }^{, 6}$ It is suggested that the food price increases have accelerated this upward trend. ${ }^{7}$ However, as Josue de Castro noted; "hunger is exclusion from land and income. When a person gets to the point of not having anything to eat, it is because all the rest has been denied. This is a modern form of exile. It is death in life" ${ }^{\text {s }}$ and as Action contre la Faim writes: "To die of hunger is equivalent to being murdered, while under-nourishment and persistent hunger are a violation of the fundamental right to life." As such, the Right to Food has been accorded universal recognition as a human right and is reflected in the international Bill of Rights to which Uganda has ratified.

\footnotetext{
${ }^{1}$ Uganda Food and Nutrition Policy, (2003): 7.

${ }^{2}$ Food and Agriculture Organisation (FAO), "The State of Food Security in the World", Economic Crises - Impacts and Lessons Learned, (2009): 11.

${ }^{3}$ Millennium Project, Halving Hunger: It Can Be Done (UN Publication, Sales No. 05.iii.B.5): 2-4

${ }^{4}$ FAO “Global Hunger Declining But Still Unacceptably High”, September 2010.

${ }^{5}$ The Right to Food, Report of the Special Rapporteur, E/CN.4/2003/54,10 January 2003

${ }^{6}$ George Kent, "The Right to Adequate Food" (2003) at www.hawaii.edu/kent

${ }^{7}$ The World Bank, "Food Price Hikes Drives 44 Million People into Poverty", Press Release No: 2011/333/PREM

${ }^{8}$ Josue de Castro Chairman of the Executive Committee of FAO (1908-1978)

${ }^{9}$ Action Against Hunger, Information Sheet, Paris, December 1997, at www.acf-fr.org
} 
In spite of the commitment to end hunger and malnutrition through legal and policy frameworks, the percentage of the undernourished in Uganda is estimated at $19 \%{ }^{10}$ and the mortality rate at 141 per 1000 live births of which more than one-third is malnutrition related. ${ }^{11}$ This clearly indicates that challenges still exist that prevent full enjoyment of the right to food in Uganda. This article therefore, discusses the protection of the right to food in international human rights law and the challenges that inhibit realisation of the right to food in Uganda. In particular, the article will address the content of the right and the obligations of the state vis-à-vis the promotion and realisation of the right to food.

\section{Existing formulations of the Right to Food in International and Regional Instruments}

The "Four Freedoms" speech ${ }^{12}$ of President Franklin D. Roosevelt outlined one of the fundamental freedoms as "freedom from want." 13 Later the Universal Declaration of Human Rights (UDHR) encompassed "freedom from want" by recognizing the Right to Food as a component of an adequate standard of living. ${ }^{14}$ Article 11 (1) of the International Covenant on Economic, Social and Cultural Rights (ICESCR) recognizes the right to an adequate standard of living including adequate food, and the right to freedom from hunger and malnutrition. ${ }^{5}$ Further, the International Covenant on Civil and Political Rights (ICCPR) recognised the right to food, through the right to life. ${ }^{16}$

Other International Conventions that recognise the right to food include; the Convention on the Elimination of All Forms of Discrimination against Women (CEDAW), which recognises the right of pregnant and lactating women to nutrition, ${ }^{17}$ the UN Convention on the Rights of the Child, ${ }^{18}$ and the Convention on the Rights of Persons with Disabilities, ${ }^{19}$ to mention only a few.

Regional instruments also provide for the right. For instance, the Additional Protocol to the American Convention on Human Rights in the Area of Economic, Social and Cultural Rights, ${ }^{20}$ the African Charter on the Rights and Welfare of the Child, ${ }^{21}$ and the Protocol to the African Charter on Human and Peoples' Rights on the Rights of Women in Africa. ${ }^{22}$ The African Commission on Human and Peoples' Rights has protected the right to food by relying on the provisions relating to the right to life, ${ }^{23}$ to health, ${ }^{24}$ and to economic, social and cultural development. ${ }^{25}$ Further, since its reaffirmation at the World Food Summit, ${ }^{26}$ the right has been recognised in conferences and non-binding international declarations such as the Voluntary Guidelines to Support the Progressive Realisation of the Right to Adequate Food. ${ }^{27}$

\section{The Right to Food and its relationship with other Human Rights}

The right to food protects the right of all human beings to feed themselves in dignity. ${ }^{28}$ This right is realised "when every man, woman and child alone or in community with others has physical and economic access at all times to adequate food or means for its procurement". ${ }^{29}$

\footnotetext{
${ }^{10}$ FAO Statistical Sheet on Uganda. www.fao.org/faostat/foodsecurity/MDG/uganda

${ }^{11}$ Ministry of Health Assessment on Uganda's Food and Nutrition Security Situation (2004)

${ }^{12}$ Franklin D. Roosevelt, "State of the Union" 26 January 1941, Roosevelt F.D. "War - And Aid to Democracies," in Rosenman S.I, The Public Papers and Addresses of Franklin Roosevelt, (New York, Macmillan Company, 1941) 672

${ }^{13}$ These freedoms became the basis of the United Nations Charter 1945, article 1 (3).

${ }^{14}$ Universal Declaration of Human Rights (UDHR) 1948, article 25.

${ }^{15}$ International Covenant on Economic Social and Cultural Rights (ICESCR), article 11

${ }^{16}$ International Covnant on Civil and Political Rights (ICCPR), article 6

${ }^{17}$ Article 12 (1) of the Convention on the Elimination of All Forms of Discrimination against Women (CEDAW), (1979) recognises the right of pregnant and lactating women to nutrition.

${ }^{18}$ Convention on the Rights of the Child (CRC), (1989) recognises the right of children to adequate nutrition in article 24 (2) (c) and (e) in the context of the right to health and in article 28 (1) in the context of the right to an adequate standard of living.

${ }^{19}$ Convention on the Rights of Persons with Disabilities, (2006) recognises the right to food in article 25 (f) in the context of the right to health.

${ }^{20}$ Protocol of San Salvador (1998), article 12

${ }^{21}$ African Charter on the Rights and Welfare of the Child, (1990) recognises the right of children to nutrition in article 14 (2) (c) (d) and (h) under the right to health

${ }^{22}$ Protocol on the African Charter on Human and People's Rights on the Rights of Women in Africa, (2003) recognises the right to food in article 15; See also article 14 (2) (a).

${ }^{23}$ Article 4

${ }^{24}$ Article 16

${ }^{25}$ Article 22, see Communication No.155/96; ACDPR/COMM/A044/1 of 27 May 2002.

${ }^{26}$ FAO, The Rome Declaration on World Food Security and World Food Summit (WFS) Plan of Action, 1996.

${ }^{27}$ Right to Food Guidelines adopted by consensus in November 2004 by the Council of FAO.

${ }^{28}$ Olivier De Schutter, A Rights Revolution: Implementing the Right to Food in Latin America and the Carribean. Special Rapporteur on the Right to Food (2012): 2 
For the Special Rapporteur on the right to food, it is "the right to have regular, permanent and free access to quantitatively and qualitatively adequate food corresponding to the cultural traditions of the people to which the consumer belongs, 30

The core contents of the right are elaborated in General Comment No.12 (8) on the Right to Adequate Food of the Committee on Economic, Social and Cultural Rights as "the availability of food in a quantity and quality sufficient to satisfy the dietary needs of individuals, free from adverse substances and acceptable to a given culture; and accessibility of such food in ways that are sustainable and that do not interfere with the enjoyment of other human rights." 31

The right to food is linked to several human rights and this is as a result of the principle of interdependence and indivisibility of human rights ${ }^{32}$ which is to the effect that, all human rights are universal, indivisible, interdependent and interrelated. ${ }^{33}$ For instance, under the African Charter on Human and People's Rights (ACHPR), the right to food is implicitly protected through the right to life, health, and economic, social and cultural development. ${ }^{34}$ Further, The Human Rights Committee observed that the protection of the right to life requires States to eliminate malnutrition. ${ }^{35}$

\section{State obligations regarding the right to food}

The Right to Food is meaningless unless it is upheld. ${ }^{36}$ Obligations are therefore, placed upon states towards the realisation of the right to food. These obligations are in terms of duties to respect, protect and fulfil. ${ }^{37}$ The obligation to respect requires States to refrain from interfering with existing levels of enjoyment of the right to food and that it guarantee existing entitlement for instance, by ensuring that those who produce their own food be secure in their access to the resources including land and water on which they depend. ${ }^{38}$ The ACHPR enforced this obligation in The Social and Economic Rights action \& Anor $v$ Nigeria by protecting the resources on which the Ogoni people depended for their livelihoods against the damage caused by oil companies. ${ }^{39}$ By doing this, the court was protecting the right to food by prohibiting actions that would undermine the ability of individuals and communities to produce their own food. In Uganda, the state has consistently interfered with the enjoyment of the right to food by evicting people from their lands. These evictions are justified in the name of promoting area development. ${ }^{40} \mathrm{~A}$ good example is the relocation of the Batwa from Bwindi forests and yet the survival of these people is in the forests.

The obligation to protect requires the State to protect individuals' enjoyment of the right to food against violations by third parties. ${ }^{41}$ In Velàsquez Rodríguez v. Honduras, ${ }^{42}$ Court held that "when a State allows private persons or groups to act freely and with impunity to the detriment of the rights recognised, it would be in clear violation of its obligations to protect the human rights of its citizens". This violation was reflected in Baleke \& others v AG of Uganda where peasants in Mubende were evicted from their land in favour of German investors.

${ }^{29}$ The Convention on Economic, Social and Cultural Rights, General Comment (GC) No. 12 (1999),paragraph 6.

${ }^{30}$ Ziegler, Jean., The Right to Food: Report by the Special Rapporteur on the Right to Food: E/CN.4/2001/53 para 14. P.7

${ }^{31}$ General Comment No. 12 (GC 12) on the Right to Adequate Food of the Committee on the Economic, Social and Cultural Rights, paras.8-13 .

${ }^{32}$ Scott, C., The Interdependence and Permeability of Human Right Norms: Towards a Partial Fusion of the International Covenants on Human Rights, 27 (4), Osgoode Hall Law Journal, P.769-878

${ }^{33}$ Vienna Declaration and Programme of Action, UN Doc. A/CONF.157/23. Para.5

${ }^{34}$ Communication No. 155/96, para. 64.

${ }_{36}^{35}$ Human Rights Committee, GC No. 6 of 1982 on the Right to Life. Par 5

${ }^{36}$ Pooja, A., The Implementation of the Right to Food at the National Level: A Critical Examination of the Indian Campaign on the Right to Food as an Effective Operationalisation of Article 11 of ICESCR. Centre for Human Rights \& Global Justice Working Paper. Series No.8 2004

${ }^{37}$ African Commission on Human and People's Rights (ACHPR) Comm. No. 155/96. The commission considers these duties as imposed at the primary level(respect), secondary level (protect), tertiary level (promote) and at fourth level (fulfil): para $42-44$

${ }^{38}$ Olivier Des Schutter, Special Rapporteure on the right to food, Interim Report on the Right to Food 2013

${ }^{39}$ Communication No.155/96; see also SERAP V Nigeria decision of 14 December 2012, this position was reaffirmed in SERAP V Nigeria decision of 14 December 2012

${ }^{40}$ Aziiza Nahalomo, et al., "Realisation of the Right to Adequate Food and the Nutritional Status of Land Evictees: A Case for Mothers/Care-Givers and Their Children in Rural Central Uganda," BMC International Health and Human Rights volume 18, Article number 21 (2018): 5

${ }^{41}$ GC para. 15; see also Union Des Jeunes Avocats/Chad Communication No. 74/92

${ }^{42}$ Judgment of July 19, 1988, Series C, No.4 
The High Court not only held agents of the State liable but also stated that "the investors should not have moved into the lands unless they had satisfied themselves that the tenants were properly compensated, relocated and adequate notice was given to them." 43

To fulfil the Right to Food, the state must engage in activities intended to strengthen people's access to and utilisation of resources and means to ensure that everyone is, at a minimum, free from hunger. ${ }^{44}$ Thus, in cases where an individual or group is unable to enjoy the right to food, the States has to fulfil the right directly. ${ }^{45}$ For instance, the state should ensure that prisoners are fed and children of the poor for example, through free school lunches. In case of natural disasters, the state should supply food aid to the vulnerable persons. ${ }^{46}$ In Uganda although the government has tried its best to fulfil this obligation, its failure is reflected in the Karamoja region which, suffers from hunger on an annual basis and despite this knowledge the funds allocated are not enough to provide basic food stuff to supplement the food needs of the Karimojong. ${ }^{47}$

Invariably, the obligations regarding the right to food are to be undertaken to the maximum of the available resources and if need be, to request aid from the resources of other governments. Despite the progressive realisation of these obligations, the state has to ensure for everyone access to the minimum essential food which is sufficient, nutritionally adequate and safe to ensure their freedom from hunger. ${ }^{48}$ This obligation is immediate as reflected in the words of Article 11(2) of the ICESCR.

\section{Implementation of the State obligations for realization of the Right to Food in Uganda}

Article 11(2) of ICESCR requires states to take appropriate steps to ensure realization of the right to food. In this regard, the right to food in Uganda is defined as a principle of state policy under the 1995 Constitution. ${ }^{49}$ National Objective XIV (b) states that:

The state shall endeavour to fulfil the fundamental rights of all Ugandans to social justice and economic development and shall, in particular, ensure that all Ugandans enjoy rights and opportunities and access to education, health... adequate clothing, food security, pension and retirement benefits.

Although the above provision does not enshrine the right as a fundamental right, it does formulate access to food as a state objective. ${ }^{50}$ Further, several legislations focus on access to food ${ }^{51}$ For example, the Penal Code Act of Uganda makes it possible to charge parents for neglecting to provide food to children under their care. ${ }^{52}$ The Land Act has been geared towards ensuring security of tenure ${ }^{53}$ Unfortunately, these laws are neither explicit on the right to food nor specific on duty bearer's roles. Only the Food and Nutrition Bill, ${ }^{54}$ has outlined the right to food roles of specific sectors.

More so, because laws are not sufficient to realize the right to food in the country, strategies based on human rights principles have been adopted.$^{55}$ For instance, within the context of the Poverty Eradication Action Plan (PEAP) ${ }^{56}$ and the Plan for Modernisation of Agriculture (PMA $)^{57}$, the Uganda Food and Nutrition Policy (UFNP) was adopted with the right to adequate food as its guiding principle. ${ }^{58}$ Subsequently, a National Food and Nutrition Strategy to guide the implementation of the Policy was drafted in 2005 with emphasis to shift from a 'basic needs approach' to a human rights based approach to food and nutrition security.

\footnotetext{
${ }^{43}$ Baleke and others v Attorney General of Uganda and others, Civil Suit 179 of 2002.

${ }^{44}$ GC 12 , para 14 and 21

${ }^{45}$ GC 12 para. 15

${ }^{46}$ Prakash Mani Sharma and others(Pro Public) v Prime minister \& Ors (writ No.0065-wo-149 of 2065 BS) 2008.

${ }^{47}$ The Right to Food: A Guide on Conducting A Right to Food Assessment At District Level in Uganda.

${ }^{48} \mathrm{GC} 12$ para 14

${ }^{49}$ Constitution of the Republic of Uganda, 1995, National Objective IV (ii) and XIV (b); see also Guideline 7(2)

${ }^{50}$ The Republic of Uganda, Uganda Food and Nutrition Policy (2003), s.2.3.9

${ }^{51}$ This is a requirement under article 2 ICESCR and GC 12 para 29

52 Penal Code Act of Uganda,s, 157

53 The Land Act 1998 CAP 227, Section 29 provides for lawful and bonafide occupants and section 31 guarantees a tenant by occupant security of occupancy.

${ }^{54}$ Uganda Food and Nutrition Bill, 25 June 2008, art 3 (a) (b)

55 These are required under GC 12 para 21 and FAO Food Guideline 3

${ }^{56}$ Poverty Eradication Action Plan for Uganda 1997.

${ }^{57}$ Plan for Modernisation of Agriculture

${ }^{58}$ Uganda Food and Nutrition Policy (2003), S.2.3.9

108
} 
Despite this however, the country still suffers from a high malnutrition burden. And although PEAP realises the need to have growing income in order to eradicate mass poverty, it does not emphasise income distribution to this effect. ${ }^{59}$

Mechanisms have also been developed to monitor progress towards the realization of the right to food ${ }^{60}$ For instance, the Uganda National Bureau of Standards (UNBS) was created to ensure food safety and improved nutrition. The other is The Uganda Human Rights Commission whose role is to monitor compliance with the right and, to examine complaints filed by aggrieved individuals and thereafter make recommendations for those with political power. ${ }^{61}$ However, since its inception, the Commission complains of inadequate funds which have prevented it from carrying out its role effectively.

The issue of remedies has also been considered since victims of violations are entitled to adequate reparation. ${ }^{62}$ Through the courts government actions are reviewed and this imposes compliance with the obligations of the State to respect, protect and fulfil the right to food. ${ }^{63}$ In Baleke \& Ors v AG of Uganda ${ }^{64}$ the victims relied on these obligations to bring a claim against government. Although remedies are available, courts have not received many cases concerning the right to food.

\section{Challenges/obstacles to the enjoyment of the right to food in Uganda}

With the supportive frameworks above, challenges still exist that have prevented the state from fulfilling its obligations. For instance, insufficient funds have been an obstacle for institutions such as the Uganda Human Rights Commission whose capacity to transverse the country to educate people on their rights ${ }^{65}$ is constrained by inadequate resources. ${ }^{66}$ Limited budgetary allocations further undermine its ability to monitor the right to food situation in Uganda. ${ }^{67}$ It is essential therefore, that the national budget assigns adequate resources for the implementation of the right to food. Related to this is poor governance, which is at the root of ills associated with food administration. With rampant corruption, even the limited funds allocated do not reach their targets. Therefore, accountable and transparent governance practices should be encouraged to help make efficient use of available resources.

The low levels of civic awareness by duty bearers on the state obligation and commitment is another challenge. There is limited knowledge of the Constitutional provisions on the right to food and the requirements under GC $12 .{ }^{68}$ This lack of awareness affects the effective implementation of the state's obligation to respect, protect and fulfil. Further, majority of the citizens are ignorant about the right to food. As such, programmes that address hunger and malnutrition are perceived as social programmes rather than human rights promotion programmes. There is need therefore, to make available information about what specific programmes are guaranteeing and what the responsibilities are of different actors as information is effective in ensuring access by citizens to entitlements. ${ }^{69}$

The lack of a special legislation on the right to food is the other challenge. Until the Food and Nutrition Bill is enacted into law, there is no specific legislation that explicitly defines the right to food roles of relevant institutions. Parliament and the Executive are therefore encouraged to work towards the adoption of a framework law. A part from legislation, the right to food can only be realized where victims have access to an independent judiciary. Rights are entitlements that should be legally protected therefore courts should be empowered to adjudicate claims without any interference.

In spite of the recognition of the non-discrimination provisions in the Constitution and the equality provisions in legislation, ${ }^{70}$ there is continued disregard of standards established by the human rights to food in implementing measures in the agricultural sector.

\footnotetext{
${ }^{59}$ Mpeirwe, A., Damulira, D., Rethinking the National Food Security Policy in Uganda. Paper No.1 of 2000

${ }^{60}$ See article 2(1) and 23 of ICESCR

${ }^{61}$ Brems et al (eds) National Human Rights Institutions and Economic, Social and Cultural Rights (Oxford 2013)

${ }^{62} \mathrm{GC} 12$ para 32.

${ }^{63}$ Christian Courtis, The Right to Food as a Justiciable Right: Challenges and Strategies" Max Planck Yearbook of United Nations Law, vol. 11, 2007 317-337

${ }^{64}$ Baleke and others v Attorney General of Uganda and others, Civil Suit 179 of 2002.

${ }^{65} 1995$ Constitution of Uganda article 52 (h)

${ }^{66}$ Uganda Human Rights Commission, $10^{\text {th }}$ Annual Report to the Parliament of Uganda, 2008

${ }^{67}$ Omara, JA., Promoting a Right-Based Approach to Food and Nutrition Security in Uganda, In Eide et al (eds) Food and Human Rights in Development, vol II Intersentia: Antwerpen-Oxford

${ }^{68}$ Rukundo P., et al, Roles and Capacity of Duty Bearers in the Realisation of the Human Rights to Adequate Food in Uganda, African Journal of Food, Agriculture Nutrition and Development Vol II No.7 2007

${ }^{69}$ L Peisakhin L., and Pinto P., Is Transparency an Effective Anti-corruption Strategy? Regulation \& Governance, vol 4 No.3 (2010) 261-280

${ }^{70}$ Land Act 1998 Cap 227 ss. $27 \& 39$
} 
The reality is that women have continued to be subjected to discrimination in terms of accessing resources, services and opportunities. This is evidenced in the Plan for Modernisation of Agriculture (PMA) that targets "to achieve food security through the market by empowering the economically active poor". ${ }^{71}$ This policy is discriminatory against vulnerable Ugandans (the majority of whom are women) who are incapacitated and lack the means to produce for the market. Also, there are still negative perceptions and inadequate recourse mechanisms to empower vulnerable rights holders who cannot fend for themselves. ${ }^{72}$ For example, women continue to be discriminated against with respect to access to and inheritance of land and loans yet these are crucial facets of the right to access to food. ${ }^{73}$ With such policies and perceptions still in place, the right to food is still a long way to be fully enjoyed by the right holders in Uganda.

\section{Conclusion}

Fulfilling the Right to Food is the fundamental responsibility of governments. As NGOs declared during the World Food Summit in 1996, "Food security is a human right which must take precedence over macro-economic and trade concerns, militarism and the dictates of the marketplace." And that achieving food security for all demands the "full engagement of all stakeholders. ${ }^{74}$ The discussion above illustrates how Uganda has addressed the issues of hunger and malnutrition. Rather than viewing hunger simply as a question of supply and demand ${ }^{75}$ the Government recognises food as a legal entitlement. It has taken measures to implement its obligation to respect, protect and fulfil the right to food through the Constitution, legislation, strategies, policies and institutions. However, despite all this, hunger and malnutrition still remain a big challenge. It is clear therefore, that government, civil society and independent monitoring institutions all have an important role to play in ensuring the progressive realisation of the right to food. For it is only when this is done that Ugandans will enjoy the right to adequate food.

\section{Bibliography}

\section{Articles}

Christian, C., (2007). The Right to Food as a Justiciable Right: Challenges and Strategies. Max Planck Yearbook of United Nations Law, Vol II,

Kent G, The Right to Adequate Food (2003)

Kikafunda J et al (eds), Risk Factors for Early Childhood Malnutrition in Uganda. American Journal of Paediatrics (1998)

Olivier Des S, A Rights Revolution: Implementing the Right to Food in Latin America and the Carribean, 2012 PP2

Omara J, Promoting a Right-Based Approach to Food and Nutrition Security in Uganda: In Eide et al (eds) Food and Human Rights in Development, Vol II Oxford

Peisakhin L \& Pinto P, Is Transparency an Effective Anti-Corruption Strategy? Regulation and Governance, Vol 4 (2010)

Pooja A, The Implementation of the Right to Food at the National Level: A Critical Examination of the Indian Campaign on the Right to Food as an Effective Operationalisation of Article 11 of ICESCR, Centre for Human Rights \& Global Justice Working Paper, Series No.8 (2004)

Rukooko B, Perception of the Right to Food in Uganda: Towards the Implementation of the Right to Adequate Food in Uganda, UHRC (2004)

Rukundo P, et al, Roles and Capacity of Duty Bearers in the Realisation of the Human Rights to Adequate Food in Uganda. African Journal of Food, Agriculture, Nutrition and Development Vol II (2007)

Scott C, The Interdependence and Permeability of Human Rights Norms: Towards a Partial Fusion of the International Covenants on Human Rights, 27 (4), Osgoode Hall Law Journal.

\footnotetext{
${ }^{71}$ Plan for Modernisation of Agriculture, Annual Report of 2004.

${ }^{72}$ Rukooko BA., Perceptions of the Right to Food in Uganda: Results from a Study, in UHRX, Towards the Implementation of the Right to Adequate Food in Uganda. Kampala, UHRC 2004; 8: 77-103

${ }^{73}$ Lwanga- Ntale, Chronic Poverty \& Disability in Uganda, (Paper Presented at conference on Staying Poor: Chronic Poverty and Development Policy at University of Manchester, Apr.7-9 2003)9

${ }^{74}$ At www.fao.org/worldfood summit/english/index.html

${ }^{75}$ Sen A., Hunger in India, Address made at a public hearing on hunger and the right to food, Delhi University, 10 January 2003, at www.geocities.com/righttofood/data/amartya.pdf 


\section{International Legal Instruments}

United Nations Charter 1945

Universal Declaration on Human Rights 1948

International Covenant on Economic Social and Cultural Rights 1966

International Covenant on Civil and Political Rights 1966

Rome Declaration on World Food Security, Rome (1996)

World Food Summit Plan of Action, Rome (1996)

\section{Government Publications}

The Constitution of the Republic of Uganda (1995)

The Plan for Modernisation of Agriculture (2000)

The Poverty Eradication Action Plan 1997

Food and Nutrition Policy ( 2003) 